\title{
The Determinants of Pay Settlements. The Influence of the National Context
}

\author{
Corresponding author: Alberto Bayo-Moriones \\ Departamento de Gestion de Empresas \\ Universidad Pública de Navarra, Pamplona, Spain \\ Phone: 34948169377 \\ Email: abayom@unavarra.es
}

\author{
Jose Enrique Galdon-Sanchez \\ Departamento de Economia \\ Universidad Publica de Navarra, Pamplona, Spain \\ IZA, Bonn, Germany \\ Sara Martinez-de-Morentin \\ Departamento de Economia \\ Universidad Publica de Navarra, Pamplona, Spain
}




\section{The Determinants of Pay Settlements. The Influence of the National Context}

This article studies the influence of national context and collective bargaining on the factors taken into account when adjusting wages. Using data from Spanish and British manufacturing establishments, we examine the relative importance of the cost of living, the ability to recruit or retain employees, the financial performance of the organisation and the industrial relations climate on wage adjustments of manual workers at the establishment level. Our findings show that there are significant differences on the importance given to these factors in both countries. In part, these are related to differences in the incidence of collective bargaining.

Keywords: collective bargaining, pay settlements, national context, wage adjustments, compensation

\section{Introduction}

The design of compensation systems in organisations is a topic that has been extensively studied in the literature. The relevance of studying compensation issues from an organisation-level point of view rests on the fact that they constitute a key component of the employment contract. Pay design is a complex issue, which is the result of different influences. Wages are not only determined by the forces of the labour market, as the competitive model predicts (see Bryson and Forth, 2008). Bargaining processes between employees and employers, no matter at which level take place, also influence wage levels. The institutions of the labour market and the political decisions adopted by governments shape the rewarding practices of firms as well. Moreover, employers participate in the process of pay determination and use payment policies as a valuable tool for managing the workforce.

Wages are reviewed when changes in the terms of the employment relationship occur, and employers' pay adjustments are also constrained by various influences such as the country's legislation and institutions, the conditions of the labour market or the 
negotiation processes with employees’ representatives. Pay reviews are not only complex, but also costly for employers. This implies that, instead of being designed on an individual basis, they are frequently carried out with a certain periodicity, embracing groups of workers. This type of wage adjustments, known as pay settlements in the terminology of collective bargaining, is the centre of our analysis.

This paper aims to contribute to the literature on pay settlements taking a, somehow, different approach to the issue than the one adopted in the previous literature. We do not simply focus on determining what the factors that influence wage adjustments are. In fact, our main objective is to study the impact that the national context has on pay settlements. In order to do so, we examine how national institutions bear upon the importance given to some specific factors when wages are adjusted. Special attention is paid to collective bargaining as an institution that plays a major role in wage determination (see Bosch, 2009; and Grimshaw, 2009).

Numerous empirical studies have focused on analysing the influence of institutions on practices such as direct communication (see Croucher et al., 2006), employee voice (see Brewster, 2007) or financial participation (see Croucher et al., 2010), among others. Drawing on this literature, our aim is to study the impact of the national context on the factors that employers take into account when adjusting wages at the establishment level.

Besides the relevance of national conditions to the adoption of HRM practices and pay policies in particular, we think that this study may contribute to the existing work on pay setting in various ways. On the one hand, it aims at analysing the determinants of pay adjustments and not simply the determinants of wage levels, which have been the main focus of the theoretical literature on wage determination so far (see Forth and Millward, 
2000). As regards the determinants of wage adjustments, Forth and Millward (2000) argue that 'in principle, every factor that bears upon (wage) levels can also bear upon adjustments'. Our opinion is that, this focus on the determinants of pay settlements may disclose differences with respect to the analysis of wage levels. This is due to two main reasons. First, pay settlements are periodic revisions of wages, so their magnitude will depend on factors that change with a certain frequency, and not on factors that could bear upon the level of pay but which are constant over time or change occasionally. Second, pay settlements affect groups of workers and not individual employees, so we expect that they are dependent of factors that influence employment conditions for the whole group of workers affected by the settlement. Taking these two considerations into account, we think that a study of the determination of wage adjustments is particularly interesting, since we should not simply extend the analysis of wage levels to the case of pay settlements. On the other hand, previous work has tried to discern the factors that employers take into account when reviewing wages, as well as their influence on the size of the adjustments (see Blanchflower and Oswald, 1988; Ingram et al., 1999; Forth and Millward, 2000; or Brown et al., 2004). However, little effort has been made to explain why these factors are taken into account by employers from an institutional perspective.

Our strategy consists of selecting four factors taken into account in the adjustment of wages: the cost of living, the ability to recruit or retain employees, the financial performance of the organisation and the industrial action. Then, we analyse the influence that the mechanism of pay determination that operates in an establishment has on the importance given to the aforementioned factors. Moreover, we examine the role 
that the national context plays in the importance given to those factors when wages are reviewed.

In order to carry out our research, we perform an empirical analysis using data from two different surveys. One of them is the well-known Workplace Employment Relations Survey 2004 (Department of Trade and Industry, 2005), a study on industrial relations and employment practices across Great Britain. The other is a newly created Spanish data set on human resource management (hereafter HRM) practices, which has its origin on a survey conducted in 2006 for a representative sample of Spanish manufacturing establishments. The fact that we have chosen Spain and the UK to perform our study is not a coincidence. Well to the contrary, we have particularly chosen to compare these two countries since they provide very different institutional scenarios. Their study constitutes a unique opportunity for evaluating the role of the national context in the pay setting processes. Our idea is that national idiosyncrasies contribute to maintain differences between countries in HRM issues and, more specifically, in pay setting decisions. Spain and the UK display certain features that make us expect differences in the factors that influence pay settlements in each country. One of these features concerns the regulatory framework: while Britain represents a 'liberal market economy' with scarce labour market regulation and little centralisation and co-ordination of collective bargaining, Spain belongs to a 'Mediterranean' category, showing a highly regulated labour market and a fragmented system of collective bargaining (see Hamman and Kelly, 2003). Another important consideration is that, according to the regulation school, the evolution of a national system can be path dependent (see Boyer, 2004; or Brewster et al., 2007). The "path dependency" idea refers to the fact that institution's activities are constrained by their historical trajectory. Aspects such as the continuity in 
the practices adopted by employers or their resistance to change, the historical legacy of the country, or the importance of the national culture could contribute to maintain intercountry differences over time. Other circumstances such as the divergence in the macroeconomic indicators and the climate of industrial relations also suggest the importance of accounting for the national context when analysing the process of pay setting at the establishment level.

The rest of the paper is structured as follows. The next section presents a theoretical examination of the factors that influence pay settlements. In the third section we outline the relationship between the mechanisms of pay determination and our factors of interest. Then, we depict the main features of the Spanish and British contexts in a comparative perspective, and we examine their expected influence on pay settlements. The following section focuses on the description of the data sets used to perform our empirical exercise. Thereafter, we concentrate on the definition of the variables used in the study and the presentation of the main findings. The final section highlights the main conclusions of the analysis.

\section{Factors that Affect Pay Determination}

Since our aim in this work is to test how the national context affects wage setting, we need to start by uncovering what the factors that influence these processes are. These factors can be grouped into two different categories, as proposed by Blanchflower and Oswald (1988). The first group includes those influences external to the establishment, as the competitive model of the labour market claims. According to this model, the determination of wages is not under the employer's control, since they are exclusively 
determined by the demand and supply of labour. This model has proved unsatisfactory for explaining wage setting processes, and a number of alternative theories of pay determination have emerged (see Bryson and Forth, 2008). These theories point to the existence of an important influence on wages of plant-specific circumstances, which leads us to the second category of factors proposed by Blanchflower and Oswald (1988). Drawing on the literature on workplace wage differentials and the theories of pay determination, and using the available data, we will focus on four factors that influence wage adjustments at the establishment level: the cost of living, the ability to recruit or retain employees, the financial performance of the firm and the industrial action. Following Blanchflower and Oswald (1988) classification, we differentiate these variables into two groups. Hence, the cost of living constitutes an influence external to the establishment, whereas the financial performance and the industrial action are plantspecific determinants of pay settlements. The ability to recruit and retain workers could be included in both groups, since it is shaped by the situation of the labour market as well as the internal conditions and management policies of the establishment. Why are these four factors determinant in wage-adjustment processes? First of all, the empirical evidence shows that most wage increases at the workplace level revolve around an element external to the establishment: the cost of living (see Blanchflower and Oswald, 1988; Ingram et al., 1999; Forth and Millward, 2000; or Brown et al., 2004). The cost of living determines, on the one hand, the purchasing power of employees. On the other, it influences, to a great extent, employers' costs and benefits (see Forth and Millward, 2000). However, these are not the only reasons. For example, employers may be prone to maintain employees' purchasing power in order to foster 
workplace morale; or they can take the cost of living as a reference for the evolution of wage levels (see Bewley, 1999).

However, there are more factors worth considering. The efficiency wage theory provides theoretical support to the argument that wage changes are influenced by companies' ability to recruit and retain employees. This theory recognises that wages that are above the market-clearing level can induce a positive effect on the effort exerted by workers. The implementation of a high-level wage system has additional implications for employers, such as the possibility of recruiting more qualified workers or the reduction of the turnover rate of the establishment (see Bryson and Forth, 2008). This leads us to think that labour needs will be undoubtedly related to employers’ pay adjustment decisions or negotiations.

Rent-sharing theories back up our idea that the financial performance of the organisation is an important variable in wage setting processes. According to these models, if an organisation generates rents and their workers possess some bargaining power, they can negotiate with employers about rent sharing (see Groshen, 1991). Therefore, pay determination is the result of a distribution of workplace rents between organisational agents (see Blanchflower et al., 1990).

Wage bargaining between employers and employees, or between their representatives, commonly creates workplace conflict due to the fact that the two groups pursue confronted objectives. The evolution of this bargaining process is influenced by the quality of the relationship between employees and managers within the workplace, which is known as the industrial relations climate (see Deery et al., 1999). Conflict can lead to industrial action, imposing great costs to the establishment. 
Among the most relevant empirical research on the factors that determine wage adjustments is the above mentioned work by Blanchflower and Oswald (1988). Using the 1984 round of the Workplace Employment Relations Survey, the authors examined the responses given by personnel managers to the question what factors influenced the level of pay decided upon in the most recent settlement? The variables more frequently cited by respondents were a mix of internal and external pressures. In light of the results, the authors concluded that wage settlements were not only determined by external pressures as the competitive model of wage determination states, but also by organisational circumstances.

Ingram et al. (1999) also referred to the distinction between external and internal pressures introduced by Blanchflower and Oswald (1988). They studied the changes both qualitative and quantitative observed in the factors that determined wage adjustments in Britain between 1979 and 1994. The authors concluded that, although the relevance of internal pressures had increased during the period, external factors continued to be determinant in the process of pay setting. Likewise, Forth and Millward (2000) examined the factors that shaped the size of pay settlements for a sample of British workplaces using information provided by the 1998 Workplace Employment Relations Survey. Taking elements from the theories of pay determination, they investigated how changes both in several within-establishment features and in external variables affected establishments’ wage adjustments. They found that, despite Britain displaying low inflation rates at the moment to which the study refers, British employers considered inflation as an important reference variable in their annual wage reviews. Comparability with other workplaces, changes in the demand 
of their products and in the supply of labour force were also important determinants of the size of pay settlements.

Brown et al. (2004) used wage-settlement data at workplace level in order to investigate the issue of nominal wage rigidity in Britain. In particular, the authors assessed the degree of nominal wage rigidity in the country between 1979 and 2001, as well as the factors that influenced the likelihood of having zero-increase adjustments. They concluded that British wage settlements were characterised by being downwards rigid during the period, and that the rate of inflation, union status, group size and firm performance were related to the probability of settling wage increases at zero. As regards the Spanish case, we have not found any studies that empirically analyse the factors that employers point to as significant when adjusting their wages using survey data at the establishment level. However, we can gain insight into this issue through a reading of the existing literature regarding the analysis of wage setting processes in the Spanish context. Hence, Bande et al. (2008) pointed to the importance of both internal variables, such as labour productivity, and external variables, such as expected alternative income, in the process of wage setting at industry level in Spain. In their analysis of wage moderation in the Spanish context, Ferreiro and Gomez (2008) described the levels of involvement of different social agents in the establishment of wage setting policies, as well as the impact of these policies on the achievement of macroeconomic goals. Finally, Raurich et al (2009) provided evidence on the factors that affect wage setting in the Spanish private sector, including variables such as the level of employment, the real GDP and average productivity as potential determinants of wages 
Therefore, we can conclude that both internal and external factors influence wage settlements, and that the cost of living, the ability to recruit or retain workers, the given establishment's financial performance and the threat of industrial action are important determinants in wage adjustment processes.

\section{Mechanisms of Pay Determination}

Prior to examining the influence of national context on pay settlements, we briefly explore the impact that the mechanism of pay determination exerts on our factors of interest. The mechanism of pay determination that operates in a workplace establishes the framework in which pay decisions are taken and imposes restrictions on wage

management by employers. In some organisations, working conditions and, particularly, pay policies are the result of bargaining processes between employers and workers’ representatives, resulting in the application of agreements that regulate the employment relationship. Collective bargaining can take place at different levels, and the interests pursued and the agreements reached may vary depending on the level at which negotiation takes place.

Hence, employers and workers' representatives can negotiate collective contracts at sector level. These agreements determine certain terms of the employment relationship such as minimum wage, job classifications or working conditions (see Gerlach and Stephan, 2006). Negotiations can also take place at firm or plant level, resulting in the establishment of a firm or plant-specific collective contract. The formalisation of this type of agreement implies the assumption of additional costs with respect to the application of a sector- level contract, but it also makes it possible for the firm or plant 
to adapt the terms of the employment relationship to its particular conditions (see Gerlach and Stephan, 2006). On the other hand, there are organisations in which pay is set unilaterally by management or negotiated individually, following considerations that can be very different from those of companies covered by collective agreements. Previous studies on this topic have shown that the mechanism of pay determination influence various dimensions of pay policies, specially wage levels and wage dispersion (see Cardoso and Portugal, 2003; Canal Dominguez and Rodriguez Gutierrez, 2004; Card and de la Rica, 2006; Dell’Aringa and Pagani, 2007; and Plasman et al., 2007). Taking all this evidence into account, we expect pay determination arrangements to play a significant role in explaining the factors taken into account when adjusting wages. Regarding the relationship with the importance given to the cost of living, it is reasonable to think that, if employees have the possibility of bargaining over wage adjustments with their employers, they will fight for maintaining their purchasing power. If this is the case, then it also seems plausible that, in those establishments where employment conditions are ruled by collective agreements (either at the sector or plant level), the cost of living is going to be regarded as a more important variable than in those other establishments where pay is determined by some other mechanisms. However, this argument is not supported by efficiency wage theories, which suggest that considerations of cost of living are likely to be equally prominent in union and nonunion firms. This is also consistent with recent analysis of union wage mark-up in Britain, which has been found to be small or non-existent (see, for example, Booth and Bryan, 2004; and Koevoets, 2007).

As far as the importance of the ability to recruit or retain employees is concerned, Card and de la Rica (2006) found that the average job tenures of workers were longer if a firm 
collective agreement was at place. This supports the hypothesis that, since organisations under firm collective agreements pay a wage premium in comparison with those companies under national or regional agreements, voluntary turnover is lower. This is also related with the presence of an internal labour market, where the number of entries and quits is low (Baron and Kreps, 1999). Therefore, under these circumstances_the firm is quite isolated from the labour market so that the need to attract new workers is reduced. At the same time, the retention of insiders is guaranteed by internal labour markets features (long-term employment, seniority-based pay and promotion from within). However, these arguments in favour of a positive effect of collective bargaining on the significance that the ability to recruit or retain employees has in pay settlements are not shared by efficiency wage theories. According to these, wages are neither purely determined by the market nor necessarily an outcome of power relations between employers and workers (Schmidt and Dworschak, 2006).

Turning to financial performance, we predict a positive relationship between the importance of this factor and the setting of working conditions at the firm level, either by collective agreement or not. In the case of collective agreements at the firm level, Gerlach and Stephan (2006) point out that 'compared to adopting an industry-level agreement, firm-level contracts impose additional transaction costs on management, but they may relax restrictions of industry-level collective agreements and adapt wages to firm-specific conditions’. Moreover, several studies have found the existence of a wage premium associated with the presence of a firm-specific contract. A commonly cited explanation for the presence of this premium is that it consists of company rents that worker representatives, having a high bargaining power, negotiate with the employer (see Card and de la Rica, 2006). On the other hand, when wage adjustments are set 
unilaterally by employers or negotiated on an individual worker-employer basis, the firm will have a greater ability to make wages flexible so that they move together with the financial performance of the firm.

Finally, we expect to find a positive relationship between the existence of collective bargaining and the importance given to industrial relations climate when pay is set. This may be due to two different reasons. On the one hand, it could be the case that collective bargaining pursues the establishment of harmonious employer-employee relations, and consequently reflects an underlying concern on the employer's side regarding the importance of creating a good working environment. On the other hand, it is possible that collective bargaining deteriorates the climate of industrial relations and increases the threat of industrial action due to the conflict of interests that can emerge during the process of negotiation. This may result in employers using wage increases as a mechanism of restoring a good working environment and, consequently, being more concerned about the importance of industrial relations climate when setting pay (see Jimenez-Martin, 2006). In addition, collective bargaining is more likely to emerge in sectors and plants where unions are powerful and, therefore, where the threats of industrial action are bigger.

\section{Country Effects}

In order to examine the influence of the national context in the determination of payments, we now compare the institutional setting in Spain and the UK. Regarding this comparison, our aim is not to make an exhaustive analysis of institutions in the two countries. On the contrary, we focus on those aspects that could influence the importance given to the cost of living, the ability to recruit or retain employees, the 
financial performance of the company and the industrial relations climate when wages are adjusted. In what follows, we revise the situation of the main macroeconomic indicators, the strictness of employment protection, the degree of industrial conflict and the different mechanisms of pay determination that characterised Spain and the UK during the period prior to the collection of the data sets used in our analysis.

It is worth mentioning that the comparison between these two countries has been previously used in the literature since they provide clear examples of different institutional approaches to industrial relations. Hence, it has been found that the differences between the two countries influence several aspects of HRM and employment relations, such as trade unions' attitudes towards the introduction of new work practices (see Ortiz, 1999) or the management of workplace flexibility (see Blyton and Martinez-Lucio, 1995). Although for different countries, other authors have also used these comparisons to assess the implications of the differences in the national framework (see for example Ferner and Quintanilla, 1998). All these studies highlight the usefulness of carrying out inter-country comparisons in order to examine the influence of national regulation and institutions on workplace issues. Regarding our first variable of interest, the cost of living, despite being an issue of major concern for governments and monetary authorities as well as a topic commonly revisited by academics, the impact of inflation on wage settlements is still not properly understood (see Brown et al., 2004). From a macroeconomic point of view, high inflation could help adjust real wages when nominal wages are rigid downwards (the socalled 'grease effect'). Alternatively, it could bring uncertainty to economic agents, resulting in a loss of efficiency in the wage setting processes (the 'sand effect'). 
Our two countries of interest display very different settings as far as inflation is concerned, which brings the opportunity to evaluate the influence of this factor on wages. In Spain, the average inflation figure between 2000-2004 was 3.3 per cent, whereas in Britain the average inflation figure for the same period was 1.2 per cent (see Table 1). From a microeconomic perspective, the cost of living is an indicator that both employers and employees take into account when offering or demanding wage increases. Linking the macro and micro dimensions of the cost of living, the dissimilar inflation environments observed in the countries under study raise some questions about its role in the wage setting behaviour of Spanish and British establishments. High inflation imposes uncertainty on economic agents’ decisions. If employees are supposed to be risk-averse, this may result in a greater importance of inflation in wage setting in Spain than in Britain in order to reduce the greater uncertainty caused by the persistence of high inflation. However, very often this problem is faced through the introduction of wage indexation clauses in labour contracts (see Jimenez-Martin, 1998). This is well reflected in the Spanish economy, where a considerable percentage of labour contracts usually contain such clauses. According to the European Industrial Relations Observatory, in 2005 wage revision clauses were included in 36.7 per cent of the collective agreements and covered 69 per cent of the workers (see EIRO, 2006). The prevalence of wage indexation in labour contracts reduces the uncertainty surrounding the adjustment of wages in response to changes in the cost of living. As a consequence, the inflation rate should be a less prominent factor in Spanish establishments when setting pay.

[TABLE 1 HERE] 
The ability to recruit and retain employees also exerts an impact on wage adjustment processes, as mentioned in the previous section. According to the turnover version of efficiency wages theory, looking for a new job is less costly for risk-averse workers when unemployment is low, which makes job mobility more likely (see Bewley, 1999). If we examine the unemployment figures in Spain and the UK, we observe that the average unemployment rate in Spain between 2000 and 2004 was 11.2 per cent, 2.5 per cent points above the EU25 average, whereas in the UK the average figure only reached the level of 5.0 per cent (see Table 1).

Sousa-Poza and Henneberger (2004) identified another institutional feature that could be related to the importance given to the need to hire and retain workers at the time of settling pay and that deserve a detailed scrutiny. This feature is the employment protection legislation (EPL) of a country, which is expected to influence not only employees’ mobility attitudes but also employers' hiring decisions. On the one hand, strict EPL provides workers with high levels of job security, which results in a low turnover propensity. On the other hand, the amount of employment protection regulation shapes the organisations' recruitment decisions. This view is also shared by Edlund and Grönlund (2008).

Our two countries of interest display important differences regarding EPL. Spain features a highly regulated labour market and employment protection is not an exception. In the UK, on the contrary, employment protection is significantly lower (see Morton and Siebert, 2001). According to OECD’s ranking of the strictness of employment legislation, in a scale ranging from 0 to 6 Spain had a score in 2003 of 3.1, whereas the score for the UK in that same year was 1.1 (see OECD, 2004). 
All these facts together, we can conclude that job mobility is lower in Spain than in Britain due to the higher unemployment rate and the stricter EPL, which diminishes turnover intentions. This suggests that British firms must compete to a greater extent in the labour market in order to hire and retain workers. Consequently, we consider that they will be more prone to take into account this issue when deciding on wage increases. The next internal variable of interest in our study is the financial performance of the firm. It is possible that the importance given to this factor is influenced by the particularities of the pay determination arrangements that operate in British and Spanish organisations (see rent-sharing theories in the second section of this paper). The structure of collective bargaining in Spain is governed by the Constitution of 1978, which guarantees the right to collective bargaining between workers' representatives and employers and protects the binding power of agreements. The Workers' Statute constitutes the legal framework regulating collective bargaining. According to the Statute, all workers are entitled to elect their representatives, who bargain over working conditions with employers' associations. Negotiations take place at national, industry or company level, but sectoral/provincial agreements are predominant. Collective agreements can be extended by law to non-affiliated firms or workers belonging to the area of negotiation (see Canal Dominguez and Rodriguez Gutierrez, 2004). As a result, bargaining coverage in Spain is high (see Table 1). Work councils negotiate employment terms at firm level, whereas the main union confederations bargain at higher levels. These unions also participate in firm-level negotiations, as an important proportion of work councils members belong to them (see Rigby et al., 2009). Conditions established at sector-level negotiations serve as benchmarking for firm 
bargaining due to the mandatory extension principle, and information circulates easily across bargaining levels (see Jimenez-Martin, 1998).

On the other hand, the system of industrial relations in the UK is characterised by the scarce legal regulation of employment relations and the voluntary character of collective bargaining. Collective agreements are not enforceable by law. Moreover, collective bargaining is highly decentralised and scarcely co-ordinated, and takes place more frequently at the company or plant level (see Hamann and Kelly, 2003). As for wage determination, the decline in collective industrial relations initiated in 1979 diminished the role of collective bargaining as the instrument used to set pay for employees. As a result, British employers have more freedom to determine wage increases without being restricted by a strong regulatory framework.

All in all, we expect that the different features of the systems of pay determination in Britain and Spain contribute to explain the observed differences between the two countries. In the previous section, we concluded that establishments where wages are set at the firm level would give more importance to financial performance. Taking into consideration the particularities of pay determination in the two countries, we anticipate that, in British establishments the influence of the financial performance will be higher than in Spanish plants.

The last relevant factor in our analysis is the industrial relations climate, which is frequently seen as a reference for evaluating a system of employee-employer relations. Wage determination processes frequently create workplace conflict, due to the fact that the two groups involved in these processes pursue different objectives. Workplace conflict may lead to industrial action, which is costly for employers. 
Our two countries display significant differences regarding this point. Strike activity in Spain is important in comparison with other EU countries and pay issues seem to be the main reason for it (see EIRO, 2007). The processes of restructuring in traditional industries such as textiles, iron and steel or shipbuilding, and the existence of general strikes that pursue political objectives (like the one in 2002) have contributed to generate conflict in the Spanish workplace (see Hamann and Martinez-Lucio, 2003). As for Britain, the conservative government imposed strong restrictions on union organisation and on industrial action as a mechanism of defence of the terms and conditions of employment. Moreover, compulsory unionism was outlawed during the period. Afterwards, the New Labour government maintained the restrictions to strike activity introduced by its predecessors. As a result, the UK has gone from being a country with important industrial disputes to one with moderate industrial action (see Scheuer, 2006). According to the International Labour Organization, in the UK only 8 working days were lost per 1000 workers due to strikes and lockouts in 2004. In Spain, this figure amounts to 116.9 days lost per 1000 workers in 2006. As it is shown in Table 1, the number of strikes and lockouts is dramatically higher in Spain in comparison with the British figure.

There is no doubt that international reports present Spain as a country with one of the worst records in Europe as far as industrial conflict is concerned (Rigby and MarcoAledo, 2001). Therefore, it seems plausible to assume that when setting pay, Spanish establishments will be more concerned about industrial action than establishments in the UK. 


\section{Data Description}

Our analysis is based on data from two sources. The first one is a Spanish data set collected in 2006 as part of a survey on HRM in the Spanish manufacturing industry. This data was gathered in 2006 through personal interviews with managers in manufacturing establishments with 50 or more employees, and represents a unique source of information about management practices in Spanish plants. Most of the information on HRM refers exclusively to blue-collar workers, that is, those workers involved directly in the production process. The reason for restricting the analysis to this category of employees lies on the existence of diverse internal labour markets with different features within the same organisation. Limiting the study to manual workers facilitates comparisons across establishments. The universe of potential respondents for the purposes of the project was constituted for all Spanish manufacturing establishments with fifty or more employees in 2005, which amounts to 6.971 units. The aim was to obtain a sample of one thousand units, in order to get conclusions that could be extended to the entire Spanish manufacturing industry. After stratification by sector, size and location, a random selection of workplaces was obtained from the Spanish Central Directory of Firms (Directorio Central de Empresas, DIRCE) of the Spanish National Statistics Institute (Instituto Nacional de Estadística, INE), using data from 2005. The final sample is constituted by a total of 1003 Spanish manufacturing plants. The British data was obtained from the WERS 2004, the fifth round of a series of surveys that have mapped industrial relations and employment practices in Great Britain since 1980. The survey collects information from managers with responsibility for employment relations or personnel matters, trade unions or employee representatives and employees themselves. It covers both private and public sectors and almost all 
industry sectors. Analogously with the Spanish survey, the unit of analysis is the workplace or establishment. For the purposes of this study, information was taken from one of the WERS 2004 sources, the Cross-Section Management Questionnaire. The main element of this survey was an interview with the senior manager at the workplace with a day-to-day responsibility for employment relations (see Kersley et al., 2006 for more information on the WERS 2004).

Finally it is worth mentioning that, in order to be able to compare plants with similar characteristics in both countries, for the British sample we only used those establishments belonging to the manufacturing sector and with 50 or more employees. Moreover, information on the mechanism of pay determination and the factors that influenced pay settlements for British establishments referred to the largest occupational group. In the Spanish case, this data was collected for manual workers, so we selected only those British cases in which the largest occupational group matched the definition of manual worker used in the Spanish questionnaire. We constructed a unique data set with only those establishments that were perfectly comparable. Finally, following Forth and Millward (2000), we chose from this sample those plants in which wages increases had taken place, as it happens in the Spanish sample. Hence, the final sample is constituted by 892 cases, 182 coming from the British survey and 710 from the Spanish one.

\section{Variables}

In what follows we describe the variables used in the empirical analysis. Their means, standard deviations and definitions are presented in Table 2.

[TABLE 2 HERE] 
Both the Spanish and British questionnaires provide information on the factors that influenced pay settlements in the establishments surveyed. The four factors considered are Changes in the cost of living, Ability to recruit or retain employees, Financial performance of the organisation and Industrial action threatened or taken. In the Spanish questionnaire, respondents were required to value the importance given to these factors when determining pay in a scale ranging from 0 (not important) to 10 (very important). In the British survey, managers were asked if the factors mentioned above influenced or not the size of pay settlements or reviews. In order to merge the information from both data sets, it was necessary to recode the Spanish scale variables into dichotomous variables. Therefore, we created new dependent variables using the following re-codification: when the response given is five or more, our dependent dummy variable takes value one, being zero otherwise. ${ }^{1}$

In order to address the issue of the influence that the country's idiosyncratic issues may have in the determination of pay a dummy variable that takes value one for British establishments and zero for Spanish ones has been used.

We also introduce in our analysis three dummy variables that state whether pay conditions at the establishment are settled through a collective bargaining at the plant or firm level, through a sector-level bargaining or by some other method. The last category includes any mechanism of pay determination different from a collective agreement at sector, firm or plant level, i.e. it includes: pay set by management at the workplace or at a higher level in the organisation, individual bargaining with employees and other mechanisms such as the use of an independent pay review body in Britain. This category is the omitted one in the empirical analysis. 
Moreover, we include several control variables. Size is captured by the logarithm of the number of employees in the establishment and Age by the logarithm of the number of years since foundation of the plant. Finally, Multinational takes value one if the firm belongs to a multinational group and zero otherwise. Finally, the Workforce representation variable is included. In the British case, this variable captures the existence of union recognition and, in the Spanish case, whether or not there is a legallybased employee representative structure, such as a work council.

\section{Results}

Since the dependent variables are dichotomous, we performed logit model estimations. For each of the dependent variables we have estimated four models. In the first one, we have included as explanatory variables the controls as well as the two dummy variables on collective bargaining. The second model includes control variables and the country dummy variable. The third model incorporates the controls, the collective bargaining variables and the country dummy. Finally, and in order to account for the possibility that the mechanisms of pay determination have different effects in the two countries under study, the fourth model includes interaction terms between collective bargaining variables and the country dummy.

We would like to start with the results obtained with regard to the importance given to the cost of living when adjusting wages (Table 3). In the first model we can see that in those workplaces where collective bargaining takes place at the firm or plant level inflation is more taken into account. The second model shows that the country variable does not exert any influence on the importance given to the cost of living. The third 
model confirms the results of the first model concerning firm-level collective bargaining. Model four shows that the interaction terms are not statistically significant, which suggests that the positive effect of collective bargaining at the firm level on the importance given to the cost of living in pay setting is the same for the two countries. Our interpretation of these results is the following. In previous sections we hypothesised that employees pursue wage rises that maintain their purchasing power in their collective negotiations with employers. Although we observe that inflation is considered a more important factor in pay settlements when a firm-level agreement is bargained, this result does not emerge in the case of an agreement at the sector level. In other words, the employees’ capacity to maintain their purchasing power under a contract negotiated at the sector level seems to be lower than we expected. This finding may be related to the claim that firm-specific contracts are agreed in those establishments where workers’ representatives are powerful (see Dell’ Aringa and Pagani, 2007). Then, employees in those establishments can exert more pressure on the employer to get wage increases that keep pace with the cost of living in comparison with workers covered by sector agreements. Despite the existence of wage indexation clauses in Spanish labour contracts, we do not observe a lower concern about the cost of living in Spanish establishments. This result is consistent with previous empirical analyses finding that most pay settlements reflect inflation to some extent, both under strict and flexible regulatory conditions, and in periods of high and low inflation (see Ingram et al., 1999; and Brown et al., 2004).

\section{[TABLE 3 HERE]}

The analysis of the importance given to the ability to recruit and retain employees also reveals interesting findings (Table 4). In the first model we find that plants where 
collective bargaining is the main mechanism of pay determination give more importance to the need to attract and retain workers. The effect is slightly larger for sector-level collective agreements than for collective agreements at the plant or firm level. The second model displays a negative and highly significant impact of the Britain dummy variable. The third model supports this country effect. However, the collective bargaining effect disappears, what suggests that country differences have to do with factors not related to the mechanisms of pay determination. This result contradicts our idea that, under a firm collective agreement, the employer gives less importance to recruitment and retention issues due to the wage premium associated with this type of agreement that reduces turnover (see Card and de la Rica, 2006). This outcome could be justified in the context of the efficiency wages theory, which arguments that wages may not be the result of power relations between employers and workers (see Schmidt and Dworschak, 2006). Hence, it seems that the importance given to the need to recruit and retain workers on pay settlements depends on factors other than the level at which collective agreements are negotiated. In the last model, when interaction terms are included, we observe a negative and significant effect of the interaction between the country dummy and the presence of a sector-level collective agreement. This means that there is a negative impact of collective bargaining on the importance given to the need to recruit and retain employees at this level, but only in Britain. The country dummy does not emerge as a significant determinant of our dependent variable in this model. Consequently, our idea that the differences in the unemployment figures and the protection of employment between Spain and the UK influence the relative importance of the need to recruit and retain workers is not supported by the findings.

[TABLE 4 HERE] 
As far as the importance of the financial performance of the organisation when adjusting wages, significant results emerge (Table 5). The first model indicates that the collective bargaining variables do not exert any significant influence on this factor. The model including the country variable clearly shows that British establishments have a higher probability of considering their financial performance when setting wages as compared to Spanish ones. In the third model both the Britain variable and the firm-level collective bargaining have positive and significant coefficients. This suggests that the differences between Britain and Spain around this issue are only partially explained by the dissimilarities in collective bargaining institutions incidence. On the one hand, those workplaces covered by their own agreement give more importance to the financial performance at the time of setting wages. As Gerlach and Stephan (2006) state, firm level agreements allow employers to adapt wages to their particular circumstances. This result may also be due to the existence of company rents that are shared with the employees due to their bargaining power (see Card and de la Rica, 2006). The findings indicate that the probability to link wages to firm performance is higher in those establishments that negotiate a firm agreement than in the plants with an alternative mechanism of pay determination, such as the employers' unilateral setting of working conditions or the bargaining at an individual level. On the other hand, other features of the national context exert an influence of the importance given to the factor of interest. In particular, our hypothesis is that the existence of a more flexible regulatory framework in the UK facilitates that employers take into account the results of the organisation when they adjust wages. The interaction terms included in the fourth model do not emerge as significant in the estimation; therefore, collective bargaining has the same effect in both countries. 


\section{[TABLE 5 HERE]}

In Table 6, the importance of industrial relations is analysed. The first model shows that this importance is related to the existence of any type of collective agreement, whether at the plant or sector level. Moreover, the Britain dummy has a large negative and highly significant effect in the second model. The third model confirms the results of these two models. This indicates that part of the country effect is associated to differences in pay determination mechanisms, whereas at the same time there is another important part that could be explained by some of the factors mentioned above in the paper. As far as the positive influence exerted by the collective bargaining variables is concerned, we suggest two plausible explanations. First, it is possible that collective bargaining occurs in those establishments where there is a concern about keeping a good climate of industrial relations, and this concern is taken into account by the employer when adjusting wages. Second, it could be the case that collective bargaining deteriorates employment relations, so that the employer increases wages in order to create a better working environment and avoid the threat of industrial action (see Jimenez-Martin, 2006). Regarding other aspects of the national context, the fact that Britain displays moderate industrial action in comparison with Spain could explain the negative coefficient of the country dummy. Finally, in the fourth model the interaction terms between the collective bargaining variables and the country dummy do not show significant coefficients.

[TABLE 6 HERE] 


\section{Conclusions}

This paper attempts to provide a more detailed account of the role that the national context and collective bargaining play in the determination of pay settlements. In particular, we analyse their influence on the importance given to the following factors at the moment of adjusting wages: the cost of living, the ability to recruit and retain employees, the financial performance of the firm and the threat of industrial action. The empirical analysis is performed for a sample of manufacturing establishments in Britain and Spain, focusing on manual workers. The UK displays low regulation of the labour market and industrial relations, whereas Spain has one of the most regulated systems in the world. Consequently, the comparison of these particular countries allows us to examine the influence of the national context on wage adjustments at the establishment level.

Several interesting findings have emerged from our analysis. A first general conclusion is that the mechanisms of pay determination play a major role in explaining the factors behind wage settlements. In spite of their institutional differences, the effects do not seem to vary between the two countries considered. Only one of the interaction terms included in the estimations appears as a significant determinant of the factors considered in pay settlements.

More specifically, firm-level collective bargaining is associated with a greater importance of cost of living. This result indicates that, under a firm-level collective agreement, workers have a higher power to negotiate wage increases that mantain their living standard. However, and contrary to our predictions, employees’ capacity to maintain their purchasing power seems to be lower under a contract at the sector level. In addition, those establishments covered by a firm collective agreement are more 
concerned about the financial performance of the organisation. As we have previously stated, this finding may be explained as a higher freedom of the employer to adapt wage outcomes to the conditions of the organisation. Alternatively, it could be due to the existence of a wage premium associated with this type of contract. Moreover, collective bargaining at whichever level is linked with more consideration of industrial action in pay review decisions. Either the setting of more harmonious employment relations under collective bargaining, or the need to restore a good industrial relations climate through wage increases, are plausible explanations of this result. On the contrary, differences in the mechanisms of pay determination do not seem to play any role in explaining the consideration of the need to attract and retain employees.

Several conclusions can be extracted from the analysis of the wage setting mechanisms. Firstly, the results concerning the cost of living correctly reflect the problems that decentralised bargaining has usually involved for wage moderation in Spain. They show that individual employers cannot control costs in this bargaining context. This is the reason why government and businesses, in conjunction with unions, have shown interest in national bargaining as a way to achieve the macroeconomic goal of low inflation (Royo, 2007).

Secondly, our results have implications for the debate on the effect of collective bargaining on wage dispersion. Theoretically, this is expected to be higher under singleemployer collective agreements, since they may increase inter-firm wage differentials by giving firms more leeway in taking into account and adapting to firm-specific characteristics and conditions (Dell’ Aringa and Pagani, 2007). Nonetheless, it has also been suggested that inter-firm wage differences in Spain and Anglo-Saxon countries may be lower under firm-level agreements because of union desire for standardisation 
(Plasman et al., 2007). We have found that, when adjusting wages, the mechanism of pay determination matters. The differences in the importance of the criteria considered most likely will lead to differences in wage levels across firms. This can be seen especially clearly in the importance of financial performance for pay setting in firmlevel bargaining: differences in performance across firms should be translated into differences in wages between firms.

Another interesting result is the similarity between sector-level collective bargaining and pay settlement not based in collective bargaining. The differences only emerge in relation to the influence of industrial action. This general pattern fits well with the observations made by Schmidt and Dworschak (2006) regarding mimetic wages. In their paper, they state that isomorphism and pay benchmarking in non-bargaining contexts act as a substitute for sector agreements, leading to similarities in pay movements. Whereas they found this effect for the UK, our study suggests it is also true of Spain.

Another fact to be underlined is that differences in the extension of single-employer and multi-employer bargaining between the two countries only capture a small part of the country effect. When significant, the coefficient of the country dummy variable remains so even when we include the collective bargaining dummies. Therefore, other factors must account for the differences in pay setting criteria. Unfortunately, the analysis of samples from two countries at a single moment in time makes it impossible to give precise details on the factors that cause these differences. To determine quantitatively whether these are differences in employment protection, macroeconomic circumstances, union power, co-ordination in bargaining or any other factor would involve analysing as many countries as possible in as many moments in time. 
We find that when wage adjusting processes are in place, Britain gives more importance to the financial performance of the firm, whereas Spain takes industrial action into account to a greater extent. The first result supports our prediction that British employers have more freedom to link wage adjustments to their performance due to the existence of a more flexible regulatory framework. Regarding the importance given to the climate of industrial relations in Spain, the result is consistent with the industrial action figures and the incidence of industrial conflict that characterise this country. In addition, these results are in line with previous empirical evidence for the UK. For example, they are congruent with the small proportion of British firms that according to Ingram et al. (1999) cite industrial action threatened or taken as an influential factor on wage increases.

The little consideration of the financial performance of the firm in pay review processes in Spain indicates that, in spite of the efforts made, the pegging of wages to productivity is still a goal to be achieved (Molina-Romo, 2005). This lack of flexibility in pay settlements has made employers search for flexibility through the high use of contingent work. This, however, leads to poor labour market outcomes such as high unemployment and excessive temporary work. A recent example of this situation can be clearly observed in the 2008-2010 economic crises. In this period not only have Spanish wages not gone down, even though the economy has required such adjustment, but also unemployment has abruptly increased.

We also consider that, albeit not so clearly, the findings regarding the inflation rate are also coherent with previous studies. Ingram et al. (1999) and Forth and Millward (2000) found that inflation is a major influence on pay settlements. In spite of the fact that the country variable is not significant, we must not forget that the comparison is made with 
Spain. This country has one of the highest inflation rates in the European Union and, therefore, represents a context where inflation is expected to play a major role in wage adjustments. The fact that Britain does not show differences with Spain in this regard seems to confirm the substantial importance of inflation in pay settlements, as has been previously concluded. Despite our expectation that differences in the unemployment rate and EPL would lead to a higher importance of the need to recruit and retain workers in Britain, the analysis does not confirm this idea. On the contrary, the regressions reveal that the mechanisms of pay determination have different effects on the factor of interest in the two countries under study. In particular, we observe a negative incidence of sector-level collective bargaining on the importance given to the need to recruit and retain workers in Britain. All in all, our results provide general support for the influence of national context and collective bargaining on pay settlements. The particularities of a country, such as the regulatory framework concerning the labour market and employment relations and the dependency of institutions on their historical trajectory, could be behind the differences in the factors that influence wage adjustments. Clearly, further research on these issues is required in order to properly explain the nature of these relationships, and there is still much to learn about the influence of national idiosyncrasies on pay settlement at review processes. Notwithstanding, we believe that this piece of research is a good starting point, since our results give evidence in favour of the idea that national institutions matter when it comes to pay decisions.

We hope that future work could contribute to improve the understanding of how wages are determined, since they constitute a primary concern for both employers and workers. Moreover, the analysis of how wage adjustments are performed and how the national context influences their formation provides valuable information that could eventually 
help to design specific labour market policies. These policies could contribute to reach some desired macroeconomic goals, such as the reduction of wage inequality or the rate of unemployment.

Obviously, our work is subject to the usual limitations related to the use of crosssectional data. In these cases, causality relationships can not be proved. Further, we have used data from two different surveys, applying different data collection methodologies or, in some minor cases, measuring variables on different scales. However, it should be noted that homogeneous samples from Britain and Spain regarding sector and occupation have been considered in our empirical analyses. This mitigates to a great extent the potential problems derived from the use of different data sets. An additional limitation associated with our study concerns the factors included as determinants of wage adjustments. Certainly, other variables may also impinge an effect on pay settlements. This is the case of the previous wage level of the establishment. Unfortunately, our data sets do not allow the formulation of a dynamic model of wage formation since they do not provide information about the previous wage level as a factor that employers may take into account when adjusting their wages. Future research on the topic should account for the process of inertia in pay settlements and use longitudinal instead of cross section data in order to construct a dynamic model of wage adjustment. 
Notes

1. This is not the only possible re-codification of the Spanish scale variables. We performed the estimations using two other transformations of the variables (six to ten on original scale takes value one in dummy variable, and two to ten on original scale takes value one in dummy variable), and the differences in the results were negligible. Eventually, we opt for the first recodification as we considered it to be the most consistent with the dichotomous measures of the dependent variables. 


\section{References}

Bande, R., Fernandez, M., and Montuega, V. (2008), 'Regional Unemployment in Spain: Disparities, Business Cycle and Wage Setting,' Labour Economics, 15, 5, 85-914.

Baron, J. N., and Kreps, D. M. (1999), Strategic Human Resources. Frameworks for General Managers, New York: John Wiley \& Sons.

Bewley, T. F. (1999), Why Wages Don't Fall During a Recession, Cambridge/London: Harvard University Press.

Blanchflower, D. G., and Oswald, A. J. (1988), 'Internal and External Influences Upon Pay Settlements,' British Journal of Industrial Relations, 26, 3, 363-370.

Blanchflower, D. G., Oswald, A. J., and Garrett, M. D. (1990), 'Insider Power in Wage Determination,' Economica, 57, 225, 143-170.

Blyton, P., and Martinez-Lucio, M. (1995), 'Industrial Relations and the Management of Flexibility: Factors Shaping Developments in Spain and the United Kingdom,' International Journal of Human Resource Management, 6, 2, 271-291.

Booth, A. L., and Bryan, M. L. (2004), 'The Union Membership Wage-Premium Puzzle: is There a Free Rider Problem?,' Industrial and Labor Relations Review, 57, 3, 402-421.

Bosch, G. (2009), 'Low-Wage Work in Five European Countries and the United States,' International Labour Review, 148, 4, 337-356.

Boyer, R. (2004), 'New Growth Regimes, But Still Institutional Diversity,' SocioEconomic Review, 2, 1-32.

Brewster, C., Croucher, R., Wood, G., and Brookes, M. (2007), 'Collective and Individual Voice: Convergence in Europe?,' International Journal of Human Resource Management, 18, 7, 1246-1262.

Brown, D., Ingram, P., and Wadsworth, J. (2004), 'The Price is Right? Pay Settlements and Nominal Wage Rigidity in Britain,' British Journal of Industrial Relations, 42, 3, 507-525.

Bryson, A., and Forth, J. (2008), 'The Theory and Practice of Pay Setting,' in The Sage Handbook of Industrial Relations, eds. P. Blyton, N. Bacon, J. Fiorito, and Edmund Heery, London: Sage Publications, pp. 491-520.

Canal-Dominguez, J. F., and Rodriguez-Gutierrez, C. (2004), 'Collective Bargaining and Within-Firm Wage Dispersion in Spain,' British Journal of Industrial Relations, 42, 3, 481-506.

Card, D., and de la Rica, S. (2006), 'The Effect of Firm Level Contracts on the Structure of Wages: Evidence from Matched Employer-Employee Data,' Industrial and Labour Relations Review, 59, 4, 573-592.

Cardoso, A. R., and Portugal, P. (2003), 'Bargained Wages, Wage Drift and the Design of the Wage Setting System,' Discussion Paper no. 914, Institute for the Study of Labour (IZA), Bonn.

Croucher, R., Gooderham, P., and Parry, E. (2006), 'The Influences on Direct Communication in British and Danish Firms: Country, 'Strategic HRM' or Unionization?,' European Journal of Industrial Relations, 12, 3, 267-286.

Croucher, R., Brookes, M., Wood, G., and Brewster, C. (2010), 'Context, Strategy and Financial Participation: a Comparative Analysis,' Human Relations, 63, 6, 835855. 
Deery, S. J., Erwin, P., and Iverson, R. (1999), 'Industrial Relations Climate, Attendance Behaviour and the Role of Trade Unions,' British Journal of Industrial Relations, 37, 4, 533-558.

Dell’ Aringa, C., and Pagani, L. (2007), 'Collective Bargaining and Wage Dispersion in Europe,’ British Journal of Industrial Relations, 45, 1, 29-54.

Department of Trade and Industry. 2005. Workplace employment relations survey: cross-section, 2004 (computer file). 1st ed. Colchester: The Data Archive (distributor), 21 December 2005. SN: 5294.

Edlund, J., and Grönlund, A. (2008), 'Protection of Mutual Interests? Employment Protection and Skill Formation in Different Labour Market Regimes,' European Journal of Industrial Relations, 14, 3, 245-264.

EIRO (2006), 'Increase in Collective Bargaining During 2005'. http://www.eurofound.europa.eu/eiro/2006/03/articles/es0603029i.htm.

EIRO (2007), Spain and United Kingdom Industrial Relations Profiles. http://www.eurofound.europa.eu/eiro/country_index.htm.

Ferner, A., and Quintanilla, J. (1998), 'Multinationals, National Business Systems and HRM: the Enduring Influence of National Identity or a Process of 'AngloSaxonization',' The International Journal of Human Resource Management, 9, 4, 710-731.

Ferreiro, J., and Gómez, C. (2008), 'Is Wages Policy on the Agenda of Trade Unions Again? Voluntary Wage Moderation in Spain,' Economic and Industrial Democracy, 29, 1, 64-85.

Forth, J., and Millward, N. (2000), 'Pay Settlements in Britain,' Discussion Paper no. 173, National Institute of Economic and Social Research, London.

Gerlach, K., and Stephan, G. (2006), 'Pay Policies of Firms and Collective Wage Contracts - an Uneasy Partnership?,' Industrial Relations, 45, 1, 47-63.

Grimshaw, D. (2009), 'Can More Inclusive Wage-Setting Institutions Improve LowWage Work? Pay Trends in the United Kingdom's Public Sector Hospitals,' International Labour Review, 148, 4, 339-459.

Groshen, E. L. (1991), 'Sources of Intra-Industry Wage Dispersion: How Much do Employers Matter?,' Quarterly Journal of Economics, 106, 3, 869-84.

Hamann, K., and Kelly, J. E. (2003), 'The Domestic Sources of Differences in Labour Market Policies,' British Journal of Industrial Relations, 41, 4, 639-663.

Hamann, K., and Martinez-Lucio, M. (2003), 'Strategies of Union Revitalization in Spain: Negotiating Change and Fragmentation,' European Journal of Industrial Relations, 9, 1, 61-78.

International Labour Organization Database on Labor Statistics (ILO Laborsta).

Ingram, P., Wadsworth, J., and Brown, D. (1999), 'Free to Choose? Dimensions of Private-Sector Wage Determination, 1979-1994,' British Journal of Industrial Relations, 31, 7, 33-49.

Jimenez-Martin, S. (1998), 'Indexation and Wage Change Settlements: Evidence from Spanish Manufacturing Firms,' Oxford Bulletin of Economics and Statistics, 60, 4, 449-484.

Jimenez-Martin, S. (2006), 'Strike Outcomes and Wage Settlements in Spain,' Labour, 20, 4, 673-698. 
Kersley, B., Alpin, C., Forth, J., Bryson, A., Bewley, H., Dix, G., and Oxenbridge, S. (2006), Inside the Workplace: Findings From the 2004 Workplace Employment Relations Survey, London: Department of Trade and Industry.

Koevoets, W. (2007), 'Union Wage Premiums in Great Britain: Coverage or Membership?,' Labour Economics, 14, 1, 53-71.

Molina-Romo, O. (2005), 'Political Exchange and Bargaining Reform in Italy and Spain,’ European Journal of Industrial Relations, 11, 1, 7-26.

Morton, J., and Siebert, W. S. (2001), 'Labour Market Regimes and Worker Recruitment and Retention in the European Union: Plant Comparisons,' British Journal of Industrial Relations, 39, 4, 505-528.

OECD (2004), Employment Outlook 2004. Paris: Organisation for Economic Cooperation and Development.

Ortiz, L. (1999), 'Union Responses to Teamwork: Differences at National and Workplace Levels,' European Journal of Industrial Relations, 5, 1, 49-69.

Plasman, R. A., Rusinek, M., and Rycx, F. (2007), 'Wages and the Bargaining Regime Under Multi-Level Bargaining: Belgium, Denmark and Spain,’ European Journal of Industrial Relations, 13, 2, 161-180.

Raurich, X., Sala, H., and Sorolla, V. (2009), 'Labour Market Effects of Public Capital Stock: Evidence for the Spanish Private Sector,' International Review of Applied Economics, 23, 1, 1-18.

Rigby, M., and Marco-Aledo, M. L. (2001), 'The Worst Record in Europe?: A Comparative Analysis of Industrial Conflict in Spain,' European Journal of Industrial Relations, 7, 3, 287-305.

Rigby, M., Contrepois, S., and O’Brien-Smith, F. (2009), 'The Establishment of Enterprise Works Councils: Process and Problems,' European Journal of Industrial Relations, 15, 1, 71-90.

Royo, S. (2007), 'Varieties of Capitalism in Spain: Business and the Politics of Coordination,' European Journal of Industrial Relations, 13, 1, 47-64.

Scheuer, S. (2006), 'A Novel Calculus? Institutional Change, Globalization and Industrial Conflict in Europe,' European Journal of Industrial Relations, 12, 2, 143-164.

Schmidt, W., and Dworschak, B. (2006), 'Pay Developments in Britain and Germany: Collective Bargaining, 'Benchmarking' and 'Mimetic Wages,' European Journal of Industrial Relations, 12, 1, 89-109.

Sousa-Poza, A., and Henneberger, F. (2004), 'Analyzing Job Mobility with Job Turnover Intentions: an International Comparative Study,' Journal of Economic Issues, 31, 1, 113-137. 
Table 1. Country Differences in Main Indicators

\begin{tabular}{l|ccc} 
& SPAIN & UK & EU25 \\
\hline Unemployment rate (Average 2000-2004) $^{1}$ & $11.2 \%$ & $5.0 \%$ & $8.7 \%$ \\
Inflation (Average 2000-2004) $^{1}$ & $3.3 \%$ & $1.2 \%$ & $2.2 \%$ \\
Employment Legislation Strictness $^{2}$ & 3.1 & 1.1 & n.a. \\
Collective Bargaining Coverage $^{1}$ & $81 \%$ & $35 \%$ & $66 \%$ \\
Degree of Bargaining Centralisation $^{1}$ & 38 & 13 & 34 \\
Strikes and Lockouts in manufacturing $^{3}$ & 359 & 30 & n.a. \\
Working Days Lost per 1000 Workers in manufacturing $^{3}$ & 116.9 & 8 & n.a.
\end{tabular}

Notes: ${ }^{1}$ Source: EIRO (2007)

${ }^{2}$ Source: OECD (2004)

${ }^{3}$ Source: ILO Laborsta. 2006 for Spain and 2004 for UK

n.a: Figure not available 


\section{Table 2. Variable Definitions and Descriptive Statistics}

\begin{tabular}{|c|c|c|c|c|c|c|c|}
\hline \multirow[t]{2}{*}{ Variable } & \multirow[t]{2}{*}{ Definition } & \multicolumn{2}{|c|}{$\begin{array}{c}\text { Total } \\
\text { Sample }\end{array}$} & \multicolumn{2}{|c|}{$\begin{array}{l}\text { Spanish } \\
\text { Sample }\end{array}$} & \multicolumn{2}{|c|}{$\begin{array}{l}\text { British } \\
\text { Sample }\end{array}$} \\
\hline & & Mean & SD & Mean & SD & Mean & SD \\
\hline Inflation & $\begin{array}{l}\text { Dummy variable: } 1 \text { if changes in the cost of living } \\
\text { influence pay settlements, } 0 \text { otherwise }\end{array}$ & 0.842 & 0.365 & 0.850 & 0.358 & 0.810 & 0.393 \\
\hline Recruitment & $\begin{array}{l}\text { Dummy variable: } 1 \text { if the ability to recruit or retain } \\
\text { employees influence pay settlements, } 0 \text { otherwise }\end{array}$ & 0.562 & 0.496 & 0.605 & 0.489 & 0.400 & 0.491 \\
\hline Performance & $\begin{array}{l}\text { Dummy variable: } 1 \text { if the financial performance of } \\
\text { the organisation influence pay settlements, } 0 \\
\text { otherwise }\end{array}$ & 0.734 & 0.442 & 0.703 & 0.457 & 0.854 & 0.354 \\
\hline Climate & $\begin{array}{l}\text { Dummy variable: } 1 \text { if industrial action threatened or } \\
\text { taken influence pay settlements, } 0 \text { otherwise }\end{array}$ & 0.626 & 0.484 & 0.777 & 0.417 & 0.050 & 0.218 \\
\hline $\begin{array}{l}\text { Sector-level collective } \\
\text { bargaining }\end{array}$ & $\begin{array}{l}\text { Dummy variable: } 1 \text { if pay set by collective } \\
\text { bargaining at sector level, } 0 \text { otherwise }\end{array}$ & 0.399 & 0.490 & 0.484 & 0.500 & 0.071 & 0.258 \\
\hline $\begin{array}{l}\text { Plant-level collective } \\
\text { bargaining }\end{array}$ & $\begin{array}{l}\text { Dummy variable: } 1 \text { if pay set by collective } \\
\text { bargaining at organisation or plant level, } 0 \text { otherwise }\end{array}$ & 0.497 & 0.500 & 0.505 & 0.500 & 0.467 & 0.500 \\
\hline $\begin{array}{l}\text { Anther mechanism of } \\
\text { pay determination }\end{array}$ & $\begin{array}{l}\text { Dummy variable: } 1 \text { if pay set some other way, } 0 \\
\text { otherwise (reference category) }\end{array}$ & 0.104 & 0.305 & 0.011 & 0.106 & 0.461 & 0.500 \\
\hline Britain & $\begin{array}{l}\text { Dummy variable: } 1 \text { if British establishment, } 0 \\
\text { otherwise }\end{array}$ & 0.204 & 0.403 & & & & \\
\hline Size & Number of employees (natural log) & 5.016 & 0.925 & 4.840 & 0.814 & 5.701 & 1.011 \\
\hline Age & Age of the establishment, in years (natural log) & 3.401 & 0.765 & 3.373 & 0.711 & 3.537 & 0.935 \\
\hline Multinational & $\begin{array}{l}\text { Dummy variable: } 1 \text { if the plant belongs to a foreign- } \\
\text { owned firm, } 0 \text { otherwise }\end{array}$ & 0.267 & 0.443 & 0.230 & 0.421 & 0.416 & 0.494 \\
\hline $\begin{array}{l}\text { Workforce } \\
\text { representation }\end{array}$ & $\begin{array}{l}\text { Dummy variable: } 1 \text { if there is union recognition for } \\
\text { the British sample or a legally-based representative } \\
\text { structure for the Spanish sample, } 0 \text { otherwise }\end{array}$ & 0.863 & 0.344 & 0.923 & 0.268 & 0.632 & 0.484 \\
\hline
\end{tabular}


Table 3. Consideration in pay settlements of the cost of living

\begin{tabular}{|c|c|c|c|c|}
\hline & Model 1 & Model 2 & Model 3 & Model 4 \\
\hline \multirow[t]{2}{*}{ Constant } & 0.390 & 0.376 & 0.464 & 1.086 \\
\hline & $(0.691)$ & $(0.638)$ & $(0.697)$ & $(1.261)$ \\
\hline \multirow[t]{2}{*}{ Size } & -0.054 & 0.063 & -0.025 & -0.046 \\
\hline & $(0.115)$ & $(0.119)$ & $(0.122)$ & $(0.123)$ \\
\hline \multirow[t]{2}{*}{ Age } & $0.234^{*}$ & $0.221 *$ & $0.236 *$ & $0.253^{* *}$ \\
\hline & $(0.124)$ & $(0.123)$ & $(0.123)$ & $(0.125)$ \\
\hline \multirow[t]{2}{*}{ Multinational } & $0.471^{*}$ & $0.536 * *$ & $0.485^{*}$ & $0.460 *$ \\
\hline & $(0.248)$ & $(0.248)$ & $(0.249)$ & $(0.250)$ \\
\hline \multirow[t]{2}{*}{ Workforce representation } & 0.075 & 0.261 & 0.050 & 0.028 \\
\hline & $(0.313)$ & $(0.279)$ & $(0.316)$ & $(0.320)$ \\
\hline \multirow[t]{2}{*}{ Sector-level collective bargaining } & 0.362 & & 0.172 & -0.349 \\
\hline & $(0.347)$ & & $(0.441)$ & $(1.084)$ \\
\hline \multirow[t]{2}{*}{ Firm-level collective bargaining } & $1.041^{* * *}$ & & $0.875^{* *}$ & 0.263 \\
\hline & $(0.351)$ & & $(0.423)$ & $(1.089)$ \\
\hline \multirow[t]{2}{*}{ Britain } & & -0.401 & -0.249 & -0.839 \\
\hline & & $(0.272)$ & $(0.354)$ & $(1.113)$ \\
\hline \multirow[t]{2}{*}{ Britain x Sector-level collective bargaining } & & & & -0.123 \\
\hline & & & & $(1.283)$ \\
\hline \multirow[t]{2}{*}{ Britain x Firm-level collective bargaining } & & & & 0.992 \\
\hline & & & & $(1.197)$ \\
\hline Chi-squared & $26.807 * * *$ & $14.464^{* *}$ & $27.291^{* * *}$ & $29.634 * * *$ \\
\hline \multirow[t]{2}{*}{$\%$ correct predictions } & 84.4 & 84.4 & 84.4 & 84.4 \\
\hline & 850 & 855 & 850 & 850 \\
\hline $\mathrm{N}$ & & & & \\
\hline
\end{tabular}

*** $\mathrm{p}<0.01,{ }^{* *} \mathrm{p}<0.05,{ }^{*} \mathrm{p}<0.10$

Note: Standard errors in parentheses 
Table 4. Consideration in pay settlements of the need to attract and retain employees

\begin{tabular}{|c|c|c|c|c|}
\hline & Model 1 & Model 2 & Model 3 & Model 4 \\
\hline Constant & $\begin{array}{c}1.529 * * * \\
(0.526)\end{array}$ & $\begin{array}{c}1.914 * * * \\
(0.497)\end{array}$ & $\begin{array}{c}1.739 * * * \\
(0.535)\end{array}$ & $\begin{array}{c}0.798 \\
(0.904)\end{array}$ \\
\hline Size & $\begin{array}{l}-0.153^{*} \\
(0.082)\end{array}$ & $\begin{array}{l}-0.059 \\
(0.086)\end{array}$ & $\begin{array}{l}-0.045 \\
(0.088)\end{array}$ & $\begin{array}{l}-0.046 \\
(0.088)\end{array}$ \\
\hline Age & $\begin{array}{l}-0.114 \\
(0.095)\end{array}$ & $\begin{array}{l}-0.101 \\
(0.096)\end{array}$ & $\begin{array}{l}-0.096 \\
(0.096)\end{array}$ & $\begin{array}{l}-0.082 \\
(0.096)\end{array}$ \\
\hline Multinational & $\begin{array}{c}-0.449 * * * \\
(0.165)\end{array}$ & $\begin{array}{c}-0.404 * * \\
(0.166)\end{array}$ & $\begin{array}{c}-0.398 * * \\
(0.167)\end{array}$ & $\begin{array}{c}-0.400 * * \\
(0.168)\end{array}$ \\
\hline Workforce representation & $\begin{array}{c}-0.811^{* * *} \\
(0.277)\end{array}$ & $\begin{array}{c}-0.823 * * * \\
(0.246)\end{array}$ & $\begin{array}{c}-0.936 * * * \\
(0.284)\end{array}$ & $\begin{array}{c}-0.881^{* * *} \\
(0.284)\end{array}$ \\
\hline Sector-level collective bargaining & $\begin{array}{c}0.918^{* * *} \\
(0.307)\end{array}$ & & $\begin{array}{c}0.275 \\
(0.357)\end{array}$ & $\begin{array}{c}1.153 \\
(0.761)\end{array}$ \\
\hline Firm-level collective bargaining & $\begin{array}{c}0.702 * * \\
(0.299)\end{array}$ & & $\begin{array}{c}0.134 \\
(0.341)\end{array}$ & $\begin{array}{c}0.979 \\
(0.760)\end{array}$ \\
\hline Britain & & $\begin{array}{c}-0.951 * * * \\
(0.214)\end{array}$ & $\begin{array}{c}-0.891^{* * *} \\
(0.248)\end{array}$ & $\begin{array}{c}0.082 \\
(0.795)\end{array}$ \\
\hline Britain x Sector-level collective bargaining & & & & $\begin{array}{l}-1.761^{*} \\
(1.042)\end{array}$ \\
\hline Britain x Firm-level collective bargaining & & & & $\begin{array}{l}-0.943 \\
(0.836)\end{array}$ \\
\hline Chi-squared & $39.709 * * *$ & $50.593^{* * *}$ & $53.058 * * *$ & $56.142 * * *$ \\
\hline$\%$ correct predictions & 60.1 & 60.5 & 61.2 & 61.2 \\
\hline $\mathrm{N}$ & 848 & 853 & 848 & 848 \\
\hline
\end{tabular}

*** $\mathrm{p}<0.01,{ }^{* *} \mathrm{p}<0.05,{ }^{*} \mathrm{p}<0.10$

Note: Standard errors in parentheses 
Table 5. Consideration in pay settlements of financial performance of the plant

\begin{tabular}{|c|c|c|c|c|}
\hline & Model 1 & Model 2 & Model 3 & Model 4 \\
\hline \multirow[t]{2}{*}{ Constant } & 0.743 & 0.431 & 0.432 & 0.569 \\
\hline & $(0.601)$ & $(0.550)$ & $(0.625)$ & $(0.929)$ \\
\hline \multirow[t]{2}{*}{ Size } & 0.104 & 0.074 & 0.004 & -0.015 \\
\hline & $(0.095)$ & $(0.098)$ & $(0.101)$ & $(0.102)$ \\
\hline \multirow[t]{2}{*}{ Age } & 0.078 & 0.060 & 0.064 & 0.087 \\
\hline & $(0.105)$ & $(0.107)$ & $(0.108)$ & $(0.109)$ \\
\hline \multirow[t]{2}{*}{ Multinational } & -0.260 & -0.258 & $-0.313^{*}$ & $-0.335^{*}$ \\
\hline & $(0.185)$ & $(0.185)$ & $(0.187)$ & $(0.188)$ \\
\hline \multirow[t]{2}{*}{ Workforce representation } & -0.320 & -0.071 & -0.220 & -0.225 \\
\hline & $(0.292)$ & $(0.269)$ & $(0.293)$ & $(0.296)$ \\
\hline \multirow[t]{2}{*}{ Sector-level collective bargaining } & -0.553 & & 0.173 & 0.090 \\
\hline & $(0.339)$ & & $(0.416)$ & $(0.747)$ \\
\hline \multirow[t]{2}{*}{ Firm-level collective bargaining } & 0.150 & & $0.808 * *$ & 0.646 \\
\hline & $(0.338)$ & & $(0.406)$ & $(0.748)$ \\
\hline \multirow[t]{2}{*}{ Britain } & & $0.834 * * *$ & $0.985^{* * *}$ & 0.856 \\
\hline & & $(0.261)$ & $(0.327)$ & $(0.801)$ \\
\hline \multirow[t]{2}{*}{ Britain x Sector-level collective bargaining } & & & & -1.039 \\
\hline & & & & $(0.994)$ \\
\hline \multirow[t]{2}{*}{ Britain x Firm-level collective bargaining } & & & & 0.655 \\
\hline & & & & $(0.917)$ \\
\hline Chi-squared & $25.431 * * *$ & $19.388 * * *$ & $35.630^{* * *}$ & $40.701^{* * *}$ \\
\hline \multirow[t]{2}{*}{$\%$ correct predictions } & 73.2 & 73.4 & 73.2 & 73.2 \\
\hline & 848 & 853 & 848 & 848 \\
\hline $\mathrm{N}$ & & & & \\
\hline
\end{tabular}

${ }^{* * *} \mathrm{p}<0.01,{ }^{* *} \mathrm{p}<0.05,{ }^{*} \mathrm{p}<0.10$

Note: Standard errors in parentheses 
Table 6. Consideration in pay settlements of industrial action threatened or taken

\begin{tabular}{|c|c|c|c|c|}
\hline & Model 1 & Model 2 & Model 3 & Model 4 \\
\hline \multirow[t]{2}{*}{ Constant } & 0.251 & $1.651^{* * *}$ & 0.786 & 1.406 \\
\hline & $(0.670)$ & $(0.636)$ & $(0.802)$ & $(0.985)$ \\
\hline \multirow[t]{2}{*}{ Size } & $-0.520 * * *$ & -0.088 & -0.138 & -0.142 \\
\hline & $(0.091)$ & $(0.111)$ & $(0.112)$ & $(0.111)$ \\
\hline \multirow[t]{2}{*}{ Age } & -0.065 & 0.027 & 0.034 & 0.029 \\
\hline & $(0.109)$ & $(0.125)$ & $(0.126)$ & $(0.126)$ \\
\hline \multirow[t]{2}{*}{ Multinational } & $-0.316^{*}$ & -0.095 & -0.105 & -0.113 \\
\hline & $(0.182)$ & $(0.214)$ & $(0.215)$ & $(0.214)$ \\
\hline \multirow[t]{3}{*}{ Workforce representation } & 0.162 & -0.054 & -0.287 & -0.356 \\
\hline & $(0.309)$ & $(0.329)$ & $(0.367)$ & $(0.380)$ \\
\hline & $3.335^{* * *}$ & & $1.136 * *$ & 0.609 \\
\hline Sector-level collective bargaining & $(0.481)$ & & $(0.570)$ & $(0.750)$ \\
\hline \multirow[t]{2}{*}{ Firm-level collective bargaining } & $3.364 * * *$ & & $1.512^{* * *}$ & 0.977 \\
\hline & $(0.478)$ & & $(0.564)$ & $(0.752)$ \\
\hline \multirow[t]{2}{*}{ Britain } & & $-4.105^{* * *}$ & $-3.753 * * *$ & $-5.045^{* * *}$ \\
\hline & & $(0.383)$ & $(0.397)$ & $(1.265)$ \\
\hline \multirow[t]{2}{*}{ Britain x Sector-level collective bargaining } & & & & 1.542 \\
\hline & & & & $(1.644)$ \\
\hline \multirow[t]{2}{*}{ Britain x Firm-level collective bargaining } & & & & 1.450 \\
\hline & & & & $(1.331)$ \\
\hline Chi-squared & $190.636^{* * *}$ & $339.023^{* * *}$ & $347.098^{* * *}$ & $348.523^{* * *}$ \\
\hline \multirow[t]{2}{*}{ \% correct predictions } & 73.8 & 81.2 & 81.2 & 81.1 \\
\hline & 850 & 855 & 850 & 850 \\
\hline $\mathrm{N}$ & & & & \\
\hline
\end{tabular}

*** $\mathrm{p}<0.01,{ }^{* *} \mathrm{p}<0.05,{ }^{*} \mathrm{p}<0.10$

Note: Standard errors in parentheses 